\title{
Система источников исламского права
}

\section{Магомедов A.M.}

Рассматривается система источников исламского права в ее историческом развитии и ее связь с возможностью применения актов международного права в мусульманских государствах. Отдельное внимание уделяется исламской правовой доктрине и ее влиянию на формирование международно-правового регулирования общественных отношений в странах ислама.

Ислам - это универсальное мировоззрение, содержащее свои концепции культуры, политики и человека, в том числе своеобразный взгляд на построение системы права, во многом отличный от европейского. Ключевой чертой, отличающей исламское право от других правовых систем, является опора на моральный авторитет мусульманского вероучения, а основой его легитимности служат не государственные установления, а божественная воля.

Наибольший интерес в практическом смысле представляет заключительная часть статьи, касающаяся трансформации норм международного и исламского права в национальные правовые системы.

Ключевые слова: ислам; система исламского права; исламско-правовая доктрина; сравнительное правоведение.

Телеология современного международного права как глобальной правовой системы предполагает, что нормы международного права должны оказывать определяющее влияние на основные составляющие общественной жизни во всех государствах планеты, определять базовые системы ценностей социально-экономического развития. Генеральной социально-политической целью международного права является обеспечение нормального функционирования существующей системы международных отношений и ее развитие. Характерная особенность современного международного права состоит в том, что стимулирование социально-экономического прогресса стало одной из главных его целей ${ }^{1}$. Устав ООН закрепил цель «содействия экономическому и социальному прогрессу всех народов». Однако реализация

\footnotetext{
* Магомедов Альберт Магомедалиевич - аспирант кафедры международного права Дипломатической академии МИД России. albert.magomedov@gmail.com.

1 Лукашук И.И. Международное право: общая часть: Учебник для студентов юридических факультетов и вузов М.: Волтерс Клувер, 2005. С. 25.
} 
целей международного права напрямую зависит от ясного понимания особенностей функционирования отдельных правовых семей и проблем, с этим связанных.

Ключевой особенностью исламского права, определяющей характер его взаимоотношений с международным правом, является система его источников, отводящая весьма специфическое место источникам международного права в правовой системе.

Прежде всего необходимо осветить систему источников исламского права в целом. Шариат представляет собой совокупность двух частей - теологии, или принципов веры (акыда), и права (фикха). Фикх, в свою очередь, делится на две части: первая указывает мусульманину, какой должна быть его линия поведения по отношению к себе подобным (муамалат), вторая предписывает обязательства по отношению к Аллаху (ибадат). Эти две части и составляют предмет юридической науки в том виде, как она определена и изучена мусульманскими правовыми школами ${ }^{2}$.

Общеизвестно, что в исламе выделяется два основных направления - суннитское и шиитское. Соответственно несколько различаются и системы источников мусульманского права.

В классической суннитской традиции мусульманского права сформировалось учение о четырех основных источниках, к которым относятся: Коран (Священное писание ислама), Сунна (свод преданий о жизни и деятельности Мухаммеда), иджма (единодушное мнение авторитетных лиц - муджтахидов) и кияс (аналогия) $)^{3}$. Таким образом, двумя главными источниками мусульманского права являются источники религии ислама: Коран и Сунна. Также выделяют некоторые второстепенные источники. Характерной чертой шиитской правовой традиции является неприятие аналогии (кияса) как источника права.

Коран - главная священная книга ислама, среди его норм, регулирующих взаимоотношения людей, заметно преобладают общие положения, имеющие форму отвлеченных религиозно-моральных ориентиров и дающие простор для толкования правоведами. Что же касается немногочисленных конкретных правил поведения, то большинство

${ }^{2}$ Теория государства и права: Учебник / Под ред. В.К. Бабаева. М.: Юристь, 2002. C. 565 .

3 См., например: Торнау Н.Е. Изложение начал мусульманского законоведения. СПб., 1850. С. 11; Давид Р., Жоффе-Спинози К. Основные правовые системы современности. М., 1996. С. 309, 310. 
из них возникло по частным случаям при решении Пророком конкретных конфликтов, оценке им отдельных фактов или в ответ на заданные ему вопросы ${ }^{4}$.

Сунна (ар. обычай, пример) - второй после Корана источник - сборник хадисов (рассказов) о поступках и высказываниях Мухаммеда, его решениях и молчаливом одобрении по вопросам веры, культовой практики и организации общины. Дополняя и истолковывая положения Корана, хадисы являются идейной основой всей правовой системы, заключают в себе дух и принципы исламского права.

Поскольку ислам признает непосредственное общение пророка с Аллахом, Сунна наряду с Кораном воспринимается верующими как богоданная основа ислама, как указание на то, какие поступки или мнения угодны Аллаху. Основной составляющий элемент Сунны - хадис (ар. новость, известие, рассказ) - включает две части: иснад (ар. опора) - перечисление тех, кто передавал друг другу известие о пророке до момента его письменной фиксации, и матн (ар. текст), содержащий конкретную информацию. Согласно мусульманской традиции, иснад представляет собой доказательство истинности того, что произошло с пророком Мухаммедом. Сунна - составная часть мусульманского религиозного образования, а ее знание является одним из главных критериев признания авторитетности богослова-правоведа и его права быть имамом 5 .

Первыми звеньями в цепи передатчиков хадисов были сахабы сподвижники и соратники Мухаммеда, люди, тесно с ним общавшиеся. За ними последовали следующие поколения хранителей и передатчиков хадисов. Первое и второе поколения после сахабов - их дети и внуки - сыграли значительную роль в кодификации ислама. Постепенно количество хадисов достигло такого размера, что стали появляться сомнения в их достоверности. В суннитском исламе в конце IX в. число хадисов превышало 600 тыс., а в шиитском - 1,5 млн 6 .

Кроме того, к фальсификации хадисов прибегали недобросовестные представители власти (для усиления своего влияния), выдававшие различные предания и изречения, не имеющие отношения к Мухаммеду,

${ }^{4}$ Сюкияйнен Л.Р. Мусульманское право. Вопросы теории и практики. М.: Главная редакция восточной литературы издательства «Наука», 1986. С. 55.

${ }^{5}$ Артемов В. Ю. Источники и доктринальные школы мусульманского права // Журнал российского права. 2007. № 3.С. 129.

6 Халиков А.Г. Хадис как источник мусульманского права: Автореф. дис. ... канд. юрид. наук. Душанбе, 1995. С. 10. 
за его деяния. К фальсификации хадисов также прибегали и представители различных противоборствующих направлений в исламе. Сложившееся положение имело негативные последствия как для ислама в целом, так и для исламского права. Тогда исламские богословы и правоведы начали кропотливую работу по выявлению сфальсифицированных хадисов и по выработке строгих критериев, которым должны отвечать подлинные хадисы ${ }^{7}$.

Каждый хадис всегда состоит из двух частей: из самого текста (матн), т.е. собственно рассказа о том или ином поступке, изречении или молчаливом одобрении Мухаммеда, и из «опоры» (иснад), т.е. перечисления непрерывной цепи пересказчиков или передатчиков хадиса, выходящей непосредственно к самому пророку ${ }^{8}$.

В соответствии с выработанными критериями отбора стали составлять сборники хадисов. К концу XII - началу XIII в. в суннитской среде было признано, что шесть тематических сборников содержат достоверный материал и могут считаться основными источниками Сунны.

С течением времени все отчетливее ощущалась недостаточность конкретных предписаний Корана и Сунны. Эти разрозненные и не представляющие единой системы правила поведения сами по себе в дальнейшем не могли обеспечить необходимой нормативной регламентации изменяющихся общественных отношений в мусульманском государстве - халифате. Поэтому начиная с VIII в. главную роль в ликвидации пробелов и приспособлении положений указанных источников к потребностям общественного развития постепенно взяли на себя правоведы - основатели правовых школ-толков и их последователи'.

К началу VIII в. исламско-правовая доктрина только начинала складываться, а до того времени не могла играть сколько-нибудь заметной роли в качестве источника действующего права. Первым же шагом на пути ее возникновения явился раи - относительно свободное

\footnotetext{
Артемов В.Ю. Источники и доктринальные школы мусульманского права // Журнал российского права. 2007. № 3. С. 131.

${ }^{8}$ Идеальным передатчиком должен быть правоверный мусульманин, правдивый и известный человек с незапятнанной репутацией, причем цепь передатчиков в идеале должна включать несколько отправных источников, не связанных политическими или деловыми интересами. Появились специальные справочники, в которых приводились биографии сподвижников Мухаммада, их учеников и нескольких поколений передатчиков. Эти биографии позволяли установить репутацию и надежность лиц, являвшихся передатчиками в цепи иснад. Таким образом, собиратель хадисов мог самостоятельно судить об их ценности. См.: Sami Zubaida. Law and Power in the Islamic World. N. Y., 2003. P. 29. 9 Сюкияйнен Л.Р. Мусульманское право. Вопросы теории и практики. С. 62.
} 
усмотрение, которое применялось при толковании Корана и Сунны и формулировании новых правил поведения в случае молчания этих источников.

C середины VIII в., когда в халифате начали складываться основные школы исламского права, наступил новый этап формирования исламско-правовой науки - «период кодификации и имамов - основателей толков (мазхабов)», который длился около двух с половиной столетий и стал эпохой зрелости, «золотыми веками» в развитии исламского права. Главным его итогом явилось возникновение различных направлений в толковании Корана и Сунны, каждое из которых относительно автономно разрабатывало собственную систему правовых норм ${ }^{10}$.

Доктринальная разработка нормативного состава исламского права теоретически базировалась на уже упоминавшемся принципе свободы иджтихада. Практически он означал введение правоведами нескольких разновидностей норм. Прежде всего, толкуя общие предписания-ориентиры Корана и Сунны, они формулировали на их основе конкретные судебные решения. Кроме того, со ссылкой на «необходимость», «интересы» общины, «пользу», изменение обычая или «основания» нормы они шли дальше отдельных конкретных предписаний Корана и Сунны, вводя новые правила. Были составлены сотни томов таких комментариев. Наконец, в случае молчания указанных источников правоведы создавали новые нормы с помощью разнообразных логических приемов, которые исламско-правовая наука и называет «рациональными» источниками исламского права. Источником таких новых норм выступала доктрина, формулировавшая их на основе указанных рациональных методов. Можно прийти к выводу, что наряду с Кораном, Сунной и судебно-нормативными решениями сподвижников пророка (вынесенными индивидуально или на основе консенсуса) именно доктрина, вобрав в себя все так называемые «рациональные» источники, стала самостоятельным источником (внешней формой) мусульманского права в юридическом смысле. Более того, в рамках доктрины была создана больщая часть норм действующего исламского права ${ }^{11}$.

Формирование основных суннитских мазхабов завершилось к X-XI вв., и в это же время возникла концепция о «закрытии врат

${ }^{10}$ Сюкияйнен Л.Р. Мусульманское право. Вопросы теории и практики. С. 68.

11 Там же. С. 69. 
иджтихада» ${ }^{12}$. После этого появление новых мазхабов стало невозможным. Отныне правоведы должны были выбирать уже существующие школы. В отличие от суннитской концепции, шиитская правовая мысль продолжала отстаивать свободу иджтихада. Но на практике и здесь нормотворческие функции сконцентрировались в руках узкой группы последователей классических шиитских толков, мнения которых считались обязательными для простых мусульман-шиитов ${ }^{13}$.

Прямая отмена пережиточных норм, пусть даже не соответствующих новым общественным потребностям, теоретически не допускалась в рамках «религиозно-правовой» системы. В этих условиях со временем исламское право превратилось в собрание огромного множества возникших в различных исторических ситуациях разнообразных норм, в большинстве случаев формально не определенных. Причем все положения данного толка были обязательны для судей и муфтиев, задача которых заключалась в выборе нужной нормы исходя из «условий, места и времени». Поэтому даже официальное санкционирование государством выводов определенной правовой школы не означало установления системы формально определенных, единообразных норм. Исламское право давало широкий простор для судейского выбора. Не случайно вплоть до настоящего времени при закреплении его норм в современном законодательстве сохраняется возможность выбирать из множества противоречивых предписаний те, которые наилучшим образом отвечают интересам социально-политических сил, стоящих у власти в той или иной мусульманской стране ${ }^{14}$, т.е. позитивное право в исламско-правовой доктрине носит вторичный характер.

Таким образом, фактический плюрализм школ дополнялся неопределенностью самих толков. Разобраться в многочисленных выводах той или иной школы и отыскать нужное правило стоило труда даже наиболее авторитетным мусульманским судьям и муфтиям. В этих условиях на передний план закономерно стала выдвигаться общетеоретическая основа исламского права. Такой вывод подтверждается, например, широким использованием мусульманскими правоведами в Средние века обычаев, категории «интереса» и юридических

${ }_{12}$ См.: Садагдар М.И. Основы мусульманского права. М., 1968. С. 11; Барковская Е.Ю. Мусульманское право и правовая культура. М., 2001. С. 7.

${ }_{13}$ Сюкияйнен Л.Р. Мусульманское право. Вопросы теории и практики. С. 69

14 Эль-Зефири Х.М.Д. Источники мусульманского права и критика их толкования современными юристами: Дис. ... канд. юрид. наук. М., 1976. С. 56. 
стратагем для приспособления исламского права к постоянно изменяющимся социальным условиям ${ }^{15}$.

В XIX в. в положении исламского права в целом и его источников произошли серьезные изменения. Они были связаны прежде всего с тем, что в правовых системах наиболее развитых мусульманских стран на первый план выходили законодательные акты, основанные на рецепции западноевропейских образцов. Наряду с этим существенное влияние на соотношение источников исламского права оказала проведенная в 1869-1877 гг. кодификация ряда его отраслей и институтов путем создания Маджаллы, которая действовала в ряде арабских стран до середины XX в. В Ливане, Иордании и Кувейте отдельные ее нормы продолжают применяться и в настоящее время ${ }^{16}$. Она явилась важным актом, закрепившим в широких масштабах нормы мусульманского права. При ее подготовке за основу были взяты известные произведения представителей ханафитской школы исламского права, в частности Ибн Нуджайма и Абу Сайда ал-Хадеми.

Для соотношения источников действующего исламского права, сложившегося с изданием Маджаллы, особое значение имели две статьи кодекса: ст. 14 запрещала иджтихад по вопросам, с достаточной полнотой урегулированным нормами закона, а ст. 1801 предусматривала, что если имеется распоряжение султана о применении по какому-либо вопросу выводов определенного толка исламского права «как наиболее соответствующего времени и интересам народа», то судья не вправе решать дело по иному толку. Примерно в то же время, когда вступала в силу Маджалла, в Египте была предпринята серьезная попытка кодифицировать право «личного статуса»: крупному ученому и государственному деятелю Мухаммаду Кадри-паше (1821-1888) власти поручили составить проект закона, посвященного данной области общественных отношений. Подготовленный им в 1875 г. вариант кодекса представлял собой свод положений мусульманского права ханафитского толка относительно «личного статуса» и в форме нормативно-правового акта предусматривал регулирование всех основных институтов данной отрасли ${ }^{17}$. Проект Мухаммада Кадри-паши не был введен в действие как официальный закон, но фактически применялся

\footnotetext{
${ }^{15}$ Ясин Камел. Источники мусульманского права. Автореф. дис. ... канд. юрид. наук. СПб., 1999. С. 43.

${ }^{16}$ Сюкияйнен Л.Р. Мусульманское право. Вопросы теории и практики. С. 75.

${ }^{17}$ Там же. С. 76.
} 
в Египте до 20-х гг. ХХ в., когда здесь появилось первое семейное законодательство ${ }^{18}$. В Тунисе аналогичную роль играл вариант семейного кодекса, составленный в 1899 г. Д. Сантилланой, а в Алжире мусульманские суды при решении семейных дел широко пользовались сводом норм маликитского толка исламского права, подготовленным в 1916 г. М. Мораном ${ }^{19}$.

В начале XX в. в мусульманских странах были приняты первые кодифицированные акты и в сфере «личного статуса». В настоящее время в большинстве из них (Египет, Алжир, Сирия, Ирак, Ливан, Тунис, Иордания, Сомали и др.) исламское право сохраняет за собой роль регулятора именно этой отрасли, в которой, как правило, действуют изданные государством нормативно-правовые акты, закрепляющие соответствующие принципы и нормы фикха. Кроме того, основанное на рецепции исламско-правовых норм законодательство регулирует правовой режим вакуфного имущества ${ }^{20}$, некоторые вопросы правоспособности, отдельные виды сделок (например, дарение).

В другой группе рассматриваемых стран (к ней можно отнести Саудовскую Аравию, Йемен, государства Персидского залива, Ливию, Иран, Пакистан, Судан) сфера действия исламского права более значительна и нередко охватывает не только право личного статуса, но и уголовное право и процесс, некоторые виды финансово-экономических отношений и даже отдельные институты государственного права. В правовых системах некоторых из них (например, Омана и других государств Персидского залива) исламское право в форме доктрины продолжает играть ведущую роль, а в других наблюдается тенденция к включению его норм во вновь принимаемое законодательство. Причем если в Йемене начиная с середины 70-х гг. вступил в силу целый ряд законов, закрепивших нормы фикха, которые ранее применялись в форме доктрины, то для правовых систем Ливии, Ирана, Пакистана и Судана в последнее время характерно усиление влияния фикха, проявляющееся в широком законодательном закреплении мусульманско-правовых норм в тех отраслях, где они до этого не действовали ${ }^{21}$.

${ }^{18}$ См подробнее: Сигалов М.К. Общее и особенное в западноевропейской и мусульманской правовой культуре. Автореф. дис. ... канд. юрид. наук. 12.00.01. М., 2006.

${ }^{19}$ Сюкияйнен Л.Р. Мусульманское право. Вопросы теории и практики. С. 77.

${ }^{20}$ Вакуф - движимое и недвижимое имущество, пожертвованное религиозным организациям. Возможное написание термина - вакф. Райзберг Б.А., Лозовский Л.Ш., Стародубцева Е.Б. Современный экономический словарь. 2-е изд., испр. М.: ИНФРА-М, 1999. ${ }^{21}$ Сюкияйен Л.Р. Мусульманское право. Вопросы теории и практики. С. 80. 
Такие серьезные изменения в позиции исламского права коснулись и его доктрины, которая выполняет различные функции в развитии правовых систем мусульманских стран ${ }^{22}$.

Прежде всего отметим, что в ряде случаев она продолжает играть роль формального источника права. Так, семейное право Египта, Сирии, Иордании, Судана и Ливана предусматривает, что в случае молчания закона судья применяет «наиболее предпочтительные выводы толка Абу Ханифы» (интересно, что мусульманские суды в Сирии со ссылкой на данную норму, как правило, применяют положения упоминавшегося труда Мухаммада Кадри-паши). Согласно марокканскому, кувейтскому и ливийскому законодательству, при отсутствии нормы в законе действуют выводы маликитского толка (поскольку в Кувейте право «личного статуса» в значительной степени некодифицированно, то данное положение означает признание мусульманско-правовой доктрины ведущим источником этой отрасли права), а сомалийский семейный кодекс обязывает судью прибегать к нормам шафиитской школы мусульманского права. В соответствии с конституцией Ирана (ст. 12) отношения «личного статуса» последователей каждого из толков ислама регламентируются нормами, принятыми соответствующей школой фикха ${ }^{23}$.

В отдельных странах допускается субсидиарное использование мусульманского права в случае пробельности любых государственных нормативно-правовых актов, а не только законодательства о праве личного статуса. Например, в Саудовской Аравии постановления верховного судебного органа от 1928 и 1930 гг. не только обязывают судей следовать в их решениях выводам ханбалитского толка, но и перечисляют произведения муджтахидов, в которых эти нормы сформулированы. В соответствии со ст. 167 конституции Ирана, если судья не находит нужной нормы в законе, он применяет положения авторитетных произведений и фетв муджтахидов. В Ливии в случае молчания законодательства также применяются выводы мусульманско-правовой доктрины различных толков ${ }^{24}$.

Законодательство отдельных стран предусматривает возможность применения в случае молчания закона не выводов определенного

\footnotetext{
22 Таилов. Р.З. Генезис мусульманского права: историко-правовой аспект. Дис. ... канд. юрид. наук. 12.00.01. СПб, 2004. С. 93.

${ }^{23}$ Сюкияйнен Л.Р. Мусульманское право. Вопросы теории и практики. С. 80.

24 Там же.
} 
толка исламского права, а его основных принципов. Подобное положение закреплено, например, в первых статьях гражданских кодексов Египта, Сирии, Ирака, Ливии и Алжира, а также в семейном законодательстве Йемена. Причем, поскольку сами гражданские кодексы закрепили ряд исламско-правовых норм, то при их толковании следует обращаться к соответствующим произведениям авторитетных мусульманских юристов.

В настоящее время доктрина остается главным источником действующего исламского права лишь в немногих странах (Саудовская Аравия, Оман, некоторые государства Персидского залива). Как правило, они закрепляются в статьях законодательства, принимаемого компетентными органами государства ${ }^{25}$. В большинстве же случаев она потеряла значение формального юридического источника, в качестве которого должен выступать нормативно-правовой акт ${ }^{26}$. Это, естественно, не означает, что можно вообще игнорировать влияние на содержание этих актов исламско-правовой доктрины.

Этому в немалой степени способствует то обстоятельство, что конституции многих указанных стран гласят, что исламское право или его принципы являются основным источником законодательства. Причем практика включения подобной нормы в основные законы неуклонно расширяется: это, в частности, было предусмотрено в конституции Ирана 1979 г. Можно обоснованно полагать, что под исламским правом здесь подразумевается доктрина, сформулировавшая подавляющее большинство его конкретных норм и все без исключения общие принципы (интересно, что в сирийской конституции применяется термин «фикх») $)^{27}$.

Этот вывод подтверждается анализом конституции Ирана: ст. 12 предусматривает соответствие судопроизводства исламскому праву, отдельно выделяя его джафаритский толк (афганская конституция 1931 г. гласила, что источником законодательства является ханафитский толк фикха). Как отмечает Р. Сикоев, в соответствии со ст. 118 Конституции Афганистана 2004 г. «судейский корпус по-прежнему

\footnotetext{
25 Там же. С. 82.

${ }^{26}$ Таилов Р.З. Генезис мусульманского права: историко-правовой аспект. Дис. ... канд. юрид. наук. 12.00.01. СПб, 2004. С. 8.

27 Пункт 2, ст. 3 Конституции Сирийской Арабской Республики от 13 марта 1973 г. «Мусульманское право (фикх) - основной источник законодательства». http:// constitutions.ru/archives/161.
} 
составляют мусульманские правоведы с высшим религиозным образованием, знатоки шариата и фикха» ${ }^{28}$.

Следует подчеркнуть, что практика включения во вновь принимаемое законодательство норм, имеющих мусульманско-правовое происхождение, в последние годы все более расширяется ${ }^{29}$. В случае коллизии основополагающих норма исламского права, закрепленных в Коране и Сунне, с нормами международного права применимыми, как правило, будут нормы исламского права. Именно этим объясняется невозможность присоединения многих исламских стран ко многим основополагающим международным договорам, например Всеобщей декларации о правах человека, или невозможность их практической реализации, а также необходимость дальнейшего развития таких региональных международно-правовых соглашений, как Всеобщая исламская декларация прав человека (1981 г.), Каирская декларация о правах человека в исламе (1990 г.) и Арабская хартия прав человека (1994 г.) и др.

\section{Библиографический список}

Артемов В. Ю. Источники и доктринальные школы мусульманского права // Журнал Российского права. 2007. № 3.

Барковская Е. Ю. Мусульманское право и правовая культура. М., 2001.

Виташов Д. С. Источники мусульманского права в общей системе источников права Афганистана. // Международное публичное и частное право. 2006. N 5.

Давид Р., Жоффе-Спинози К. Основные правовые системы современности. М., 1996.

Лукашук И. И. Международное право: общая часть: учебник для студентов юридических факультетов и вузов М.: Волтерс Клувер, 2005.

Садагдар М. И. Основы мусульманского права. М., 1968.

Сигалов М. К.: Общее и особенное в западноевропейской и мусульманской правовой культуре: автореферат дис. ... кандидата юридических наук : 12.00.01, М.: 2006.

28 Сикоев Р. Основной закон 2004 года в контексте афганского конституционализма // Азия и Африка сегодня. 2004. № 6. С. 26-29.

${ }^{29}$ См., например: Виташов Д.С. Источники мусульманского права в общей системе источников права Афганистана // Международное публичное и частное право. М.: Юрист, 2006. № 5. 
Сикоев Р. Основной закон 2004 года в контексте афганского конституционализма // Азия и Африка сегодня. 2004. N 6.

Сюкияйнен Л. Р. Мусульманское право. Вопросы теории и практики, М.: Главная редакция восточной литературы издательства «Наука»,1986.

Сюкияйнен Л. Р. Шариат и мусульманско-правовая культура. М.: Институт государства и права Российской академии наук, 1997.

Таилов Р.З., Генезис мусульманского права: Историко-правовой аспект: диссертация ... кандидата юридических наук : 12.00.01, Спб: 2004.

Теория государства и права: Учебник / Под ред. В.К. Бабаева. М.: Юристь, 2002.

Торнау Н.Е. Изложение начал мусульманского законоведения. СПб., 1850.

Халиков А. Г. Хадис как источник мусульманского права: Автореф. дис. ... канд. юрид. наук. Душанбе, 1995.

Шарль Р. Мусульманское право. М.: Издательство иностранной литературы, 1959.

Эль-Зефири Х.М.Д. Источники мусульманского права и критика их толкования современными юристами: Дис. ... канд. юрид. наук. M., 1976.

Ясин Камел. Источники мусульманского права: Автореф. Дис. ... канд. юрид. наук. СПб., 1999.

Sami Zubaida. Law and Power in the Islamic World. N. Y., 2003. 


\section{The System of Sources of Islamic Law (Summary)}

\section{Albert M. Magomedov*}

The article deals with the system of sources of Islamic law in its historical development and its possibility of applying acts of the international law in Muslim countries. Special attention is paid to the Islamic legal doctrine and its influence on the formation of international legal regulation of social relations in the Islamic countries. Islam can be treated as universal outlook, containing its own concepts of culture, politics and rights, including an original perspective on the construction of legal system different from Europe, whose experience could be useful for the development of world-wide legal system. A key feature that distinguishes the Islamic law from other legal systems is the reliance on the moral authority of the Muslim religion and the basis of its legitimacy are not public service, but divine will. The main interest in a practical sense provides the final part of the article concerning the transformation of Islamic law in national legal systems.

Keywords: Islam; Islamic law; legal system; law; comparative law.

\footnotetext{
*Albert M. Magomedov - post-graduate student of the Chair of International Law, Diplomatic Academy MFA Russia. albert.magomedov@gmail.com.
} 